\title{
Potential Analysis of Baccharis Dracunculifolia and Baccharis Trimera for Phytoremediation of Heavy Metals in Copper Mining Tailings Area, Southern Brazil
}

\section{Thays Afonso}

UFPEL: Universidade Federal de Pelotas

\section{Carolina Demarco}

UFPEL: Universidade Federal de Pelotas

\section{Simone Pieniz}

UFPEL: Universidade Federal de Pelotas

\section{Maurízio Quadro}

UFPEL: Universidade Federal de Pelotas

\section{Flávio Camargo}

UFRGS: Universidade Federal do Rio Grande do Sul

Robson Andreazza ( $\square$ robsonandreazza@yahoo.com.br)

Federal University of Rio Grande do Sul https://orcid.org/0000-0001-9211-9903

\section{Original Article}

Keywords: Environmental damage, Contaminated soils, Phytoremediation, Heavy metals

Posted Date: February 9th, 2021

DOl: https://doi.org/10.21203/rs.3.rs-174219/v1

License: (c) (i) This work is licensed under a Creative Commons Attribution 4.0 International License.

Read Full License

Version of Record: A version of this preprint was published at Applied Biochemistry and Biotechnology on September 10th, 2021. See the published version at https://doi.org/10.1007/s12010-021-03652-3. 
Potential analysis of Baccharis dracunculifolia and Baccharis trimera for phytoremediation of heavy metals in copper mining tailings area, Southern Andreazza $^{1^{*}}$

91 Science and Engineering of Materials Postgraduate Program, Technological 10 Development Center, UFPel, Pelotas, RS, Brazil.

112 Environmental Sciences Postgraduate Program, Engineering Center, UFPel, 12 Pelotas, RS, Brazil.

$13{ }^{3}$ Department of Soil Science, Agronomy Faculty Federal University of Rio Grande do 14 Sul, Porto Alegre, RS, Brazil.

15 *Corresponding author: e-mail: robsonandreazza@yahoo.com.br; Phone +55 53 163921 1432; Fax +55 5339211432. 


\section{Abstract}

The aim of this study was to investigate the phytoremediation potential promoted by Baccharis dracunculifolia DC. and Baccharis trimera (Less.) DC. incopper mining tailings area, Southern Brazil. The plants were selected considering their spontaneous growth on tailings. The phytoremediation indexes as a translocation factor (TF), bioconcentration factor (BCF), metal extraction ratio (MER) and plant effective number (PEN) were carried out. Both species showed higher concentration of heavy metals in the roots in relation to the shoots. $B$. trimera showed potential for phytoextraction of $\mathrm{Zn}, \mathrm{Cd}, \mathrm{Cr}, \mathrm{Pb}$ and phytostabilization of $\mathrm{Ba}$ and $\mathrm{Ni}$, whereas $\mathrm{B}$. dracunculifolia showed potential for phytoextraction $\mathrm{Pb}$ and phytostabilization of $\mathrm{Cu}$, $\mathrm{Zn}$, and $\mathrm{Ba}$. B. trimera showed higher potential in phytoremediation of the metals $\mathrm{Cu}>\mathrm{Zn}>\mathrm{Cr}>\mathrm{Ni}$ and $\mathrm{Cd}$ than the $B$. dracunculifolia. $B$. trimera requires a smaller number of plants to remove $1 \mathrm{~g}$ of $\mathrm{Cu}, \mathrm{Zn}, \mathrm{Cr}, \mathrm{Pb}$, Niand $\mathrm{Cd}$ than the $B$. dracunculifolia. The values of PENs for $\mathrm{Cu}$ were close to those estimated for $B$. dracunculifolia, but the PENs $(\mathrm{Cu})$ and PENt $(\mathrm{Cu})$ in $B$. trimera are much lower, meaning that a smaller number of plants are required for decontamination. Both species showed potential for phytoremediation of metals and grew spontaneously in the tailing mining area.

Keywords Environmental damage, Contaminated soils, Phytoremediation, Heavy metals 
50 The abundance of mineral resources in Brazil is well known. Brazil has about 207

51 actived mines, producing a wide variety of industrial minerals, including metals ( $\mathrm{Al}$,

$52 \mathrm{Cu}, \mathrm{Cr}, \mathrm{Fe}, \mathrm{Mg}, \mathrm{Nb}, \mathrm{Ni}, \mathrm{Au}, \mathrm{V}$ and $\mathrm{Zn}$ ), and it is almost $80 \%$ of its production [1].

53 Mining activity is essential for society, and economy.However, in current years, the

54 disruption of the tailings dams of Brumadinho (2019) and Mariana (2015) brought worldwide prominence to Brazil due to the environmental liabilities generated [2]. It was evident that the country has been facing problems regarding the proper control and management of its mining tailings.

Mine tailings are generated after the mineral processing, and consist in a mixture of rock (solid waste) composition that varies according to the type of ore [3]. The generation of mine tailings can affect the quality of the environment and contributes to high concentrations of heavy metals, whether in soil and/or water [4, 5].

Due to the high content of heavy metals, tailings pose a health risk to the both aspects, chemical and physical [6]. their translocation to and accumulation in aboveground biomass i.e., shoots [8]. Plants that do not transport the metals to the shoots, but instead bind them in the root 
or the rhizosphere, are preferred by phytostabilization $[9,10]$. Both techniques are a way to investigate whether a species has potential for phytoremediation.

The species Gazania rigens e Pelargonium hortorumthat, occur naturally in a copper mining tailings area in Chile, are an example of plants that showed potential in the phytoremediation of heavy metals [11]. However, the species

B. trimera (carqueja) and B. dracunculifolia (Alecrim-of-the-field), although identified in some studies in copper and gold mining areas in southern Brazil $[12,13,14]$ are still poorly studied for phytoremediation purposes.

Both species belong to the family Asteraceae. They are a rustic, perennial and dioecious shrub, native to the southern and southeastern regions of Brazil [15, 16], and in South America [17, 18, 19, 20].

B. dracunculifolia plays an important role in the colonization and regeneration of contaminated areas $[21,22]$, being considered in Brazil as a secondary vegetation or, in regeneration and advanced stages of regeneration, that is resulting from natural processes of ecological succession [23]. Some studies have shown that both species have the ability to accumulate heavy metals in their biomass [13, 14, 24].

In this context, the aim of this study was to investigate the phytoremediation potential promoted by $B$. dracunculifolia and $B$. trimera in copper mining tailings area, Southern Brazil.

\section{Materials and Methods}

\section{Study area}

Camaquã Mines belongs to the municipality of Caçapava do Sul, which it is located in the Southern region of Brazil, state of Rio Grande do Sul (Figure 1). 
The Camaquã Mines belongs to the Pampa Biome characterized by a vegetation of the wooded steppe type [25]. The climate is temperate of the subtropical type, classified as humid mesotherm and the region is located in the sub-basin of Arroyo João Dias [26].

The soils that comprise the Camaquã Mine region are classified as AChernozemic [27]. The Camaquã Mine region is marked by what remains of the copper mining and it is located on plane levels of mining tailings where the open pit (already mined area) has been filled.

Camaquã Mines region contain one of the largest deposits of basic copper metals associated with $\mathrm{Pb}-\mathrm{Zn}$ in the southern of Brazil. The exploration of the base metals (mainly copper) has occurred since the $19^{\text {th }}$ century [28]. The region, includes the tailings of Uruguay Mine (Cu) (closed in 1996) which is the specific area of this study.

\section{Plant samples and elements detection}

Both species $B$. trimera and $B$. dracunculifolia, are colonist plants on the copper mining tailings of the Uruguay mine. $B$. trimera obtained an average total dry biomass of $2.4 \pm 0.7 \mathrm{~g}$ (roots), $4.8 \pm 2.8 \mathrm{~g}$ (shoots), and an average height of $42.0 \pm 4.0 \mathrm{~cm}$, while B. dracunculifolia showed an average height of $33.5 \pm 12.0 \mathrm{~cm}$ and dry biomass of $0.9 \pm 0.6 \mathrm{~g}$ (roots), $3.9 \pm 2.2 \mathrm{~g}$ (shoots).

The plants $(n=12)$ were sampled in the copper mining tailings area. The sampling was performed in the summer season (2017) and the collected material was packed in stored in properly identified bags and taken to laboratory. The samples of plants were washed individually and divided into shoots and roots and fresh weight was determined. Afterwards, the biomasses were dried in an oven at $70 \stackrel{\circ}{C}$ for 48 hours and ground to a homogeneous power[29]. For the digestion process, it was used a 
3:1 concentrated nitric-perchloric acid $\left(\mathrm{HNO}_{3}-\mathrm{HClO}_{4}\right)$ according to the methodology

123 described by Tedesco et al. [30]. The determination of the elements was performed by ICP-OES (PerkinEImer ${ }^{\circledR}$ - version Optima ${ }^{\text {TM }} 8300$ ).

\section{Chemical analyses of tailings}

127 Sample collection of the copper mining tailings was taken from a sampling composed

128 of five replications at a depth of 0 to $20 \mathrm{~cm}$, obtained mainly from the copper mining 129 tailings of the Uruguay Mine (Closed at 1998) in the region of Caçapava do Sul -RS, 130 Brazil (Figure 1).

131 The tailings samples were dried at room temperature, crushed and sieved $(3 \mathrm{~mm})$ 132 prior to analysis. The Physico-chemical properties of the material were determined 133 (Table 1). The $\mathrm{pH}$ ratio in water is 1:1.5; (w/v) adapted from the methodology in 134 Landon [31]; CEC: Cation Exchange Capacity; P, Na, Cu and Zn (extractable): 135 extracted with $0.1 \mathrm{M} \mathrm{HCl}$; $\mathrm{Mg}$ (exchangeable): extracted with $1.0 \mathrm{M} \mathrm{KCl} ; \mathrm{H}+\mathrm{Al}$ : 136 titration; sulfur (S): extracted with $500 \mathrm{M}$ of calcium phosphate; organic matter (O.M) 137 by wet digestion; $\mathrm{Cd}, \mathrm{Ni}, \mathrm{Cr}, \mathrm{Pb}, \mathrm{Mo}, \mathrm{Ba}$ [32]; using internal standards for control and 138 verification of procedures (with recovery between 81 and 105\% for metals and Limits 139 of Detection (LD) of: $\mathrm{Cd}-0.2 ; \mathrm{Cr}$ and $\mathrm{Ni}-0.4 ; \mathrm{Cu}-0.6 ; \mathrm{Pb}$ and $\mathrm{Zn}-2.0 ; \mathrm{ug} / \mathrm{g}$.) and, 140 determined by ICP-OES.

\section{Metal accumulation}

143 Once determined the elements in the roots and shoots systems, as well as in the 144 tailings, it was determined the phytoremediation indexes to evaluate the plant's ability 145 to remediate the contaminated area. 
Translocation factor (TF) and Bioconcentration factor (BCF) are parameters to

147 study the soil-to-plant transfer accumulation of heavy metals [33]. The parameters

148 evaluate the phytoextraction potential of the plants.

149 Translocation factor value is represented in according to the following Equation 1.

150 Translocation factor value greater than 1 indicates the translocation of the metal from

151 root to above-ground part (tailings in this case)[34].

$152 \mathrm{TF}=\frac{[\text { metal }] \text { shoots }}{[\text { metal }] \text { roots }}(1)$

154 Where, [metal] shoots and [metal]roots are the metals concentrations in dry biomass (mg $\left.155 \mathrm{~kg}^{-1}\right)$.

157 The bioconcentration factor (BCF) that is used to calculate the distribution of 158 heavy metals between sediment (tailings in this case) and plant is defined by

159 Equation 2. According to Yoon et al. [8] and Kamari et al. [35], only plant species with 160 both BCF and TF greater than 1 have the potential to be used for phytoextraction.

$161 \quad \mathrm{BCF}=\frac{[\mathrm{metal}] \text { roots }}{[\text { metal] tailings }}(2)$

163 Where, [metal] roots is the metals concentration in the dry biomass $\left(\mathrm{mg} \mathrm{kg}^{-1}\right)$ and 164 [metal] tailings is metals concentration in the tailings $\left(\mathrm{mg} \mathrm{kg}^{-1}\right)$.

The metal extraction ratio (MER) was also determined. This index expresses the

167 capacity of accumulation of metal in the shoots of the plant in relation to that in the

168 tailings [36] (Equation3).

$169 \operatorname{MER}=\left(\frac{[\text { Cplant] X [ Mplant }]}{[\text { Ctailings] X [zone Mrooted }]}\right) 100$ 
170 Where, [Cplant] is the concentration of the metal in the plant ( $\left.\mathrm{mg} \mathrm{kg}^{-1}\right)$; [Mplant] is the

171 dry weight biomass; [Ctailings] is the concentration of the metal in the tailings ( $\mathrm{mg} \mathrm{kg}^{-}$

$1722^{1}$ ) and [zone Mrooted] is the tailings volume occupied by the plant (value adopted of 1

$173 \mathrm{~kg})$.

175 To determine the number of plants required to extract $1.0 \mathrm{~g}$ of element or metal of 176 interest, the PENs (plant effective number) were determined, which considers the 177 biomass of the shoots of the plant and the PENt that takes into calculation the total 178 biomass of the plant (shoots and roots)[37]. Both the PENs and PENt were 179 determined considering the concentration of the target element present in the dry 180 biomass of the plants as well as the dry weight biomass. It was used following 181 equation:

183 PENs $=\frac{\text { level }_{\text {shoots }} \times \text { mass }_{\text {shoots }}}{1000}(4)$

185 PENt $=\frac{\text { level }_{\text {entire }} \text { plant } X \text { mass }}{\text { entire } \text { plant }}(5)$

The phytoremediation potential $\left(\mathrm{g} \mathrm{ha}^{-1}\right)$ was estimated considering the total 188 concentration of the target metal in the plant and weight biomass. For this, the dry 189 biomass production of the plant was estimated considering on studies by Santos et al. 190 [38] for B. dracunculifolia (3.86514 $\left.\mathrm{t} \mathrm{ha}^{-1}\right)$ and Amaral et al. [16] (10.3 $\left.\mathrm{t} \mathrm{ha} \mathrm{h}^{-1}\right)$ for $B$. 191 trimera, multiplied by the total concentration of each target metal in the plant (total 192 mgkg $^{-1}$ ). 
The experimental design was completely randomized and the software Statistica®

194 version 7.0 was used. It was performed Analysis of Variance (ANOVA), and the

195 Tukey test $(p<0.05)$ was carried out when ANOVA showed significant results.

\section{Results}

\section{Nutrients uptake and heavy metal contents in biomass}

198 The behaviour of both species $B$. trimera and $B$. dracunculifoliain relation to the 199 concentration of macronutrients in the roots was similar. The $B$. trimera showed the 200 following sequence of macronutrient concentrations $\mathrm{Ca}>\mathrm{K}>\mathrm{Mg}>\mathrm{S}>\mathrm{P}$, whereas in the 201 B. dracunculifolia $\mathrm{Ca}>\mathrm{K}>\mathrm{S}>\mathrm{Mg}>\mathrm{P}$, being the sulphur concentration $\left(1,956.8 \mathrm{mg} \mathrm{kg}^{-1}\right)$ 202 higher than the concentration of magnesium $\left(1,142.1 \mathrm{mg} \mathrm{kg}^{-1}\right)$ in $B$. trimera 203 (Figure2A).

204 The concentrations of the elements in B. trimera shoots showed the following 205 order, $\mathrm{Fe}>\mathrm{Na}>\mathrm{Al}>\mathrm{Mn}>\mathrm{Cu}>\mathrm{Zn}>\mathrm{Ni}>\mathrm{Co}$, whereas in $B$. dracunculifolia the order was $206 \mathrm{Fe}>\mathrm{Al}>\mathrm{Na}>\mathrm{Mn}>\mathrm{Cu}>\mathrm{Zn}>\mathrm{Ni}>\mathrm{Co}$ (Figure2B). Even with an inversion between the 207 aluminum and sodium sequences between the species, the other metals followed the 208 same order in both species (Figure2B). In the roots, this elements concentration 209 followed the same order in both species B. trimera and B. dracunculifolia $210(\mathrm{Fe}>\mathrm{Al}>\mathrm{Na}>\mathrm{Cu}>\mathrm{Mn}>\mathrm{Zn}>\mathrm{Ni}>\mathrm{Co})$.

211 The concentration of $\mathrm{Cu}$ in shoots of $B$. dracunculifolia was almost half of the 212 concentration shown by the $B$. trimera (Figure2B). The same behaviour was occurred 213 with the concentrations of $\mathrm{Cu}$ in the roots, being more than twice in $B$. trimera, when 214 compared to B. dracunculifolia (Figure2B).

215 The concentrations of $\mathrm{Ni}$ in the shoots were similar between the species(Figure2B).

216 The B. trimera showed higher concentrations of all elements in both shoots and roots, 217 except for $\mathrm{Zn}$ and $\mathrm{Ni}$, compared with B. dracunculifolia (Figure2B). 
Both species presented similar concentrations of heavy metals in roots than in

219 shoots, except for Cd and V (Figure2C).

\section{Phytoremediation index}

222 The translocation factor (TF) in B. dracunculifolia was higher than one (TF>1) for Fe,

$223 \mathrm{Cd}, \mathrm{Cr}, \mathrm{Pb}$ and $\mathrm{Zn}$. In $B$. trimera, only $\mathrm{Pb}$ obtained value of $\mathrm{TF}>1$ (Table 2).In $B$. 224 dracunculifolia, the bioconcentration factors greater than one $(B C F>1)$ were detected 225 for the metals $\mathrm{Zn}, \mathrm{Cd}, \mathrm{Cr}, \mathrm{Ni}, \mathrm{Pb}$ and $\mathrm{Ba}$; however, the $\mathrm{B}$. trimera showed the $\mathrm{BCF}>1$ 226 for $\mathrm{Cu}, \mathrm{Zn}, \mathrm{Pb}$ and $\mathrm{Ba}$ (Table 2).

227 Both species showed TF>1 for $\mathrm{Pb}$ and $\mathrm{BCF}>1$ for $\mathrm{Zn}, \mathrm{Pb}, \mathrm{Ba}$. The species $B$. 228 dracunculifolia showed $\mathrm{BCF}>1$ and $\mathrm{TF}>1$ for metals $\mathrm{Zn}, \mathrm{Cd}, \mathrm{Cr}, \mathrm{Pb}$ and $\mathrm{BCF}>1$ and $229 \mathrm{TF}<1$ only for $\mathrm{Ba}$ (Table 2). However, B. trimera showed BCF $>1$ and TF>1 only for $230 \mathrm{~Pb}$ and $\mathrm{BCF}>1$ and $\mathrm{TF}<1$ for the metals $\mathrm{Cu}, \mathrm{Zn}, \mathrm{Ba}$ (Table 2).

231 Both B. dracunculifolia and B. trimera exhibited high value MER index for 232 extraction of $\mathrm{Zn}$ and Ba metals (Table 2). Although, MER index of $\mathrm{Cr}$ and $\mathrm{Pb}$ were 233 not so high in both species, they were higher than one $(M E R>1)$. Considering the 234 copper element, only the $B$. trimera obtained MER>1 (Table 2).

235 The $B$. trimera species requires a smaller number of plants to remove $1 \mathrm{~g}$ of $\mathrm{Cu}$, $236 \mathrm{Zn}, \mathrm{Cr}, \mathrm{Pb}, \mathrm{Ni}, \mathrm{Cd}$, for both PENs and PENt in relation to B. dracunculifolia (Table 2).

237 Regarding the presented results, B. trimera species showed a higher potential in 238 phytoremediation of $\mathrm{Cu}>\mathrm{Zn}>\mathrm{Cr}>\mathrm{Ni}>\mathrm{Cd}$ than $B$. dracunculifolia (Figure3). While $B$. 239 trimera showed potential to remove $6,039.60 \mathrm{gha}^{-1}$ of $\mathrm{Cu}$, the $B$. dracunculifolia would 240 remove $992.10 \mathrm{~g} \mathrm{ha}^{-1}$, even that, it is a good potential of the $B$. dracunculifolia. The 241 specie $B$. trimera would remove more than twice as much $\mathrm{Cd}$ and $\mathrm{Pb}$ as $B$. 242 dracunculifolia (Figure3). 


\section{Discussion}

245 There is an increasing search for species of plants which are able to adapt to areas 246 under extreme conditions such as copper mining tailings in the Camaquã Mines. The 247 impacted physical structure of mining tailings, the low nutrient content and high 248 concentration of heavy metals restricts the conditions for proper development of plant 249 species[14].

250 In this context the species $B$. dracunculifolia and $B$. trimera are growing 251 spontaneously under the copper mining tailings. Species of the genus Baccharis, 252 such as $B$. trimera and $B$. dracunculifolia naturally vegetate environments such as 253 roadsides, steep and high-altitude areas, acidic or mildly acidic soils with elevated 254 contents of $\mathrm{Al}, \mathrm{Ca}, \mathrm{Mg}, \mathrm{K}$ and low $\mathrm{P}$ content [39]. The species also showed good 255 development and adaptation in altered or disturbed sites [40,41], as it is the case 256 ofthe cooper tailings area in the Mines of Camaquã region.

257 B. trimera and B. dracunculifolia were in early stages of development over the 258 copper mining tailings area in the present study, since the $B$. trimera height ranges 259 from $0.5-1.6 \mathrm{~m} \mathrm{[42].} \mathrm{The} \mathrm{height} \mathrm{of} B$. dracunculifolia usually ranges from 2-4 $\mathrm{m}[17$, $26020,43]$

261 Therefore, depending on the period of development in which species are, the 262 production of dry biomass can variety. The biomass production of $B$. trimera, for 263 example, infertile soils can variety from 3.5 to $10.3 \mathrm{t} \mathrm{ha}^{-1}$. However, under natural 264 conditions, the value ranges from 0.046 to $47.9 \mathrm{t} \mathrm{ha}^{-1}[16,44,45]$.

265 Some studies have shown that the production of the biomass of $B$. trimera can 266 achieve $21.89 \mathrm{~g} \mathrm{plant}^{-1}[16]$. In $B$. trimera with a mean height of $33.5 \mathrm{~cm}$, the dry 267 biomass in the roots was $0.9 \mathrm{~g} \mathrm{plant}^{-1}$, and in the shoots $3.9 \mathrm{~g} \mathrm{plant}^{-1}$, whereas $B$. 
268 dracunculifolia with a mean height of $20-30 \mathrm{~cm}$, the dry biomass was $1.58 \mathrm{~g} \mathrm{plant}^{-1}$ for

269 roots and $6.14 \mathrm{~g} \mathrm{plant}^{-1}$ for shoots [16, 46, 47]. Values are much higher than those 270 found in this study.

271 The increase in the biomass production of both species would enhance their ability 272 to phytoremediation, as a copper mining tailings area in this study. The variation in 273 biomass production is related to the amount of nutrients available in the mining tailing.

274 Thus, fertilization generates an increase in the biomass production of $B$. trimera 275 (carqueja) to a certain extent [39]. In highly fertile soil, $B$. trimera does not respond to 276 mineral or organic nitrogen fertilization, meaning that $B$. trimera develops well with 277 low N, P and K contents [16], as the species in the present study.

278 Plants in mining areas in Southern Brazil are called "savanna metallophile" and 279 presents mechanisms of tolerance and resistance to heavy metals [48], as the 280 species $B$. trimera and $B$. dracunculifolia in mining tailings area. It is commonly the 281 presence of species of the family Asteraceae in areas that are in the process of 282 environmental regeneration. Melo-Júnior et al. [49] in a floristic survey in a degraded 283 region found more than 16 species of the Asteraceae family, among them were the $B$. 284 dracunculifolia and B. crispa.

285 Some species of the genus Baccharis are already known as indicative of the initial 286 stages of environmental regeneration (B. trimera) and indicative of primary 287 vegetation of the middle and advanced stages of regeneration (B. dracunculifolia) 288 according to the Brazilian legislation [23]. This was verified in this study for both 289 species, even after 24 years of passive vegetation, since 1996 that was finished the 290 activities in the mine.

291 Depending on the ability of plants to adapt under adverse conditions, the species 292 showed different phytoremediation mechanisms, capable of extracting or stabilizing 
293 metals, in the soil or in their system [50], as is the case of $B$. trimera and $B$. 294 dracunculifolia, which showed mechanisms of phytoextraction, phytoaccumulation 295 and phytostabilization of metals (Table 2).

296 Both species seem to face difficulties in translocation of some metals to the shoots, 297 this suggests resistance mechanisms, such as the exclusion of metals [51]. Thus, the 298 transfer of the metal to the plant prevents it from accumulating this metal in its shoots 299 biomass. This can be seen in the analysis of Table 2.

300 When evaluating native plants in mining areas, Estrada et al. [52] found that higher 301 concentrations of $\mathrm{Cu}, \mathrm{Pb}$, and $\mathrm{Zn}$ in roots biomass in different species studied were 302 higher in the species of impacted areas (mining) than in other areas. This difference 303 was observed by the authors in concentrations of $\mathrm{Pb}\left(158 \mathrm{mgkg}^{-1}\right), \mathrm{Cu}\left(689 \mathrm{mg} \mathrm{kg}^{-1}\right)$, 304 and $\mathrm{Zn}\left(514 \mathrm{mg} \mathrm{kg}^{-1}\right)$ in $B$. dactyloides, among others. This can also be seen in the 305 species $B$. trimera and $B$. dracunculifolia, which presented high concentrations of 306 metals and their biomass (Figures2and 3).

307 Other studies have also demonstrated high concentration of metals in the biomass 308 of plant species growing under the area of mining tailings, for example, Menares et al. 309 [53] determined low concentrations of $\mathrm{Cu}, \mathrm{Zn}, \mathrm{Mg}$ and $\mathrm{Fe}$ in the species $B$. linearis 310 under tailings of copper mining in Chile. In contrast, both $B$. dracunculifolia and $B$. 311 trimera showed very high $\mathrm{Cu}$ and Fe concentrations in the biomass compared to 312 results obtained by Menares et al. [53].

313 The metals accumulated in shoots indicate that $B$. dracunculifolia is more efficient 314 in translocation of $\mathrm{Zn}, \mathrm{Fe}, \mathrm{Cd}, \mathrm{Cr}$ and $\mathrm{Pb}$ than $B$. trimera, which showed high 315 efficiency only for lead. Resistance mechanisms may be involved as low absorption, 316 permeability and or active efflux of the metals by $B$. trimera, which reflects in the low 317 translocation of these metals [54]. 
The translocation factor for $\mathrm{Cu}, \mathrm{Pb}$ and $\mathrm{Zn}$ were higher than one for all species studied by Estrada et al. [52] in soils contaminated with heavy metals, such as $P$. incanum, also a native of Rio Grande do Sul (Brazil), which obtained TF=2 for lead and $\mathrm{TF}=3$ for $\mathrm{Cu}$ and $\mathrm{Z}$. B. sarotroidesgrowing in copper mining areas showed high

322 translocation values for the metals $\mathrm{Cu}, \mathrm{Cr}$, and $\mathrm{Mo}[55]$.Translocation factors found by

323 these authors were higher than those found in $B$. dracunculifolia and $B$. trimera for 324 the same metals (Table 2). High concentration of metals in the roots may be due a 325 slow translocation considering the exposure to high concentration of metals in 326 tailings[56]. Nevertheless, the $B$. dracunculifolia has potential for phytostabilization 327 and phytoaccumulation for application in the recovery of areas contaminated with 328 toxic metals $[47,57]$.

329 When the metal is transferred from the soil to the biomass of the plant, the plant 330 uses mechanisms such as exudation, that send toxic compounds to isolate sites, 331 such as apoplast, in order to avoid their entry into the symplast [58]. In this way, the 332 plant restricts the absorption and translocation of the metals, demonstrating tolerance 333 to the metal. Therefore, typical symptoms of intoxication were not shown in the $B$. 334 dracunculifolia and $B$. trimera, since both species showed similar tolerance to 335 concentrations which were considered to be toxic by Kabata-Pendias [59] for the 336 metals Cu (20-100 mgkg $\left.{ }^{-1}\right)$, Cr (5-30 mg kg-1) and Ni (10-100 mg kg-1).

337 The $B$. dracunculifolia is a species that achieves a high survival in places with low 338 nutrient concentration [22] being indicated for environmental regeneration [60, 61] 339 because it presents a good adaptation in degraded areas [62]. This was shown in the 340 study of Boechat et al. [13] in which B. trimera, in gold mining areas in Southern 341 Brazil obtained metal contents $(\mathrm{Cu}, \mathrm{Zn}, \mathrm{Cd}, \mathrm{Ni}, \mathrm{Pb}, \mathrm{Ba})$ higher than those found in 342 this study for the same species (Figures 2and 3). Whereas, Silva et al. [63] showed 
343 low concentration of metals ( $\mathrm{Cd}, \mathrm{Co}, \mathrm{Cr}, \mathrm{Cu}, \mathrm{Pb} \mathrm{Zn})$ in the whole plant of $B$. trimera.

344 Although, B. trimera shows variations in terms of metals concentration in its biomass,

345 it showed TF>1 for metals $\mathrm{Zn}, \mathrm{Cd}, \mathrm{Pb}$ and $\mathrm{BCF}>1$ for $\mathrm{Cu}, \mathrm{Zn}, \mathrm{Cd}$ and $\mathrm{Ba}$ [13],

346 demonstrating its potential in phytoremediation of metals.

347 On steel slag, the species $A$. thaliana had low biomass production, low BCF and

$348 \mathrm{TF}$, but MER>1\% for $\mathrm{Cd}(\mathrm{MER}=7.7 \%)$, $\mathrm{Cu}(\mathrm{MER}=8.1 \%)$ and $\mathrm{Pb}(\mathrm{MER}=1.8 \%)$ [64].

349 The rate of extraction of the metal is related to the production of biomass by the plant

350 so that the more biomass promotes higher rate of extraction of the metal [36, 64].

351 Thus, both B. trimera and B. dracunculifolia presented lower extraction rates for $\mathrm{Cu}$,

$352 \mathrm{~Pb}, \mathrm{Cd}$ compared to $A$. thaliana but presented very high rates for $\mathrm{Zn}$ and $\mathrm{Ba}$.

353 Analyzing the phytoremediation factors in the $B$. trimera and $B$. dracunculifolia, it

354 can be seen that $B$. trimera showed a potential for phytoextraction (TF>1 and $B C F>1)$

355 of $\mathrm{Zn}, \mathrm{Cd}, \mathrm{Cr}, \mathrm{Pb}$ and phytostabilization $(\mathrm{TF}<1$ and $\mathrm{BCF}>1)$ of $\mathrm{Ba}$ and $\mathrm{Ni}$, whereas $B$.

356 dracunculifolia showed potential for phytoextraction of $\mathrm{Pb}$ and phytostabilization of

$357 \mathrm{Cu}, \mathrm{Zn}$ and $\mathrm{Ba}$. In phytostabilization, plants immobilize the metals in the rhizosphere

358 while in phytoextraction they translocate the metals to the shoots [50].

359 In this context, the potential of $B$. trimera and $B$. dracunculifolia in the removal of 360 heavy metals contained in contaminated soils is higher than those found by 361 Andreazza et al. [65] in the species B. pilosa (Asteracea family). According to the 362 author, this species had characteristics of hyperaccumulating $\mathrm{Cu}$. In $\mathrm{Cu}$ 363 contaminated soils, B. pilosa would need 83,001 shoots of plants for the copper 364 removal (PENs in inceptisol) and 3,536 whole plants (PENt in mollisol) also for Cu.

365 The values of PENs for $\mathrm{Cu}$ were close to those estimated for $B$. dracunculifolia, 366 but the PENs $(\mathrm{Cu})$ and PENt $(\mathrm{Cu})$ in $B$. trimera are much lower, meaning that a 367 smaller number of plants are required for decontamination (Figure3). Both species ( $B$. 
trimera and $B$. dracunculifolia) present a phytoremediation potential in areas

369 contaminated with heavy metals.

\section{Conclusions}

371 The results showed that $B$. trimera showed potential for phytoextraction of $\mathrm{Zn}, \mathrm{Cd}, \mathrm{Cr}$,

$372 \mathrm{~Pb}$ and phytostabilization of $\mathrm{Ba}$ and $\mathrm{Ni}$, whereas $\mathrm{B}$. dracunculifolia showed potential

373 for phytoextraction of $\mathrm{Pb}$ and phytostabilization of $\mathrm{Cu}, \mathrm{Zn}$, and $\mathrm{Ba}$ in tailings area.

374 Both species showed a high ratio of $\mathrm{Zn}$ and Ba metals extraction.

375 Considering the copper element, only $B$. trimera obtained MER $>1$, which it showed

376 the potential to remove $\mathrm{Cu}$. Besides, $B$. trimera requires a smaller number of plants

377 to remove $1 \mathrm{~g}$ of $\mathrm{Cu}, \mathrm{Zn}, \mathrm{Cr}, \mathrm{Pb}, \mathrm{Ni}, \mathrm{Cd}$, comparing to $\mathrm{B}$. dracunculifolia.

378 The values of PENs for copper were close to those estimated for $B$. dracunculifolia, 379 but the PENs $(\mathrm{Cu})$ and PENt $(\mathrm{Cu})$ in $B$. trimera are much lower, meaning that a 380 smaller number of plants are required for decontamination. It is concluded that $B$. 381 trimera showed a higher phytoremediation potential of $\mathrm{Cu}>\mathrm{Zn}>\mathrm{Cr}>\mathrm{Ni}>\mathrm{Cd}$ metals in 382 relation to $B$. dracunculifolia, although both species exhibited potential to be applied 383 in phytoremediation in tailings area.

384 The results must be viewed carefully, as they are the initial data of an in-situ 385 experiment. I consider plants to behave differently in other areas. Therefore, this 386 work opens space for new studies involving such plants.

388 Authors' Contributions TFA and RA conceptualized the study. TFA performed the 389 main experimental work, evaluated the dataset, and wrote the main text of the 390 manuscript. TFA and FAOC performed the analyses. SP, MSQ and CFD were 391 involved in proofreading of the manuscript. 
393 Funding Information This study was financed in part by the Coordenação de Aperfeiçoamento de Pessoal de Nível Superior - Brasil (CAPES) - Finance code 001, by the CNPq (National Council for Scientific and Technological Development) and FAPERGS (Research Support Foundation of the State of Rio Grande do Sul).

Data Availability The datasets used and/or analyzed during the current study are available from the corresponding author on reasonable request.

\section{Compliance with Ethical Standards}

Competing Interests The authors declare that they have no competing interests.

Ethics Approval and Consent to Participate Not applicable. The manuscript does not contain data collected from humans or animals.

Consent for Publication Not applicable. The manuscript does not contain any 409 individual person's data.

\section{References}

1 ANM. (2020). Agência Nacional de Mineração. Anuário Mineral Brasileiro: Principais Substâncias Metálicas / Coord. Técnica de Marina Dalla Costa et al. Brasília(BR): ANM.

2 MMA. (2020). The disruption of a mining tailings dam in Mariana and Brumadinho, in the Brazilian state of Minas Gerais. Brasília (BR): MMA.

3 IBRAM. (2016).Gestão de Rejeitos de Mineração. Brasília (BR): IBRAM.

4 Sağlam, E. S., Akçay, M. (2016). Chemical and mineralogical changes of waste and tailings from the Murgul Cu deposit (Artvin, NE Turkey): implications for occurrence of acid mine drainage.Environ. Sci. Pollut. Res.,23(7), 6584-6607.

5 Zhang, Q., Li, Y., Phanlavong, P., Wang, Z., Jiao, T., Qiu, H., Peng, Q. (2017). Highly efficient and rapid fluoride scavenger using an acid/base tolerant 
zirconium phosphate nanoflake: behavior and mechanism. J. Cleaner Prod., 161, 317-326.

6 Ali, H., Khan, E., Sajad, M. A. (2013). Phytoremediation of heavy metalsConcepts and applications. Chemosphere,91, 869-881.

7 Mahmoud, R. H., Hamza, A. H. M. (2017). Phytoremediation application: plants as biosorbent for metal removal in soil and water. In: A.A. Ansari et al. editors. Phytoremediation. Springer International Publishing. doi:10.1007/978-3-31952381-1_15

8 Yoon, J., Cao, X., Zhou, Q., Ma, L.Q. (2006). Accumulation of Pb, Cu, and Zn in native plants growing on a contaminated Florida site. Sci. Total Environ.,368, 456-464.

9 Zeng, P., Guo, Z., Cao, X., Xiao, X., Liu, Y., Shi, L. (2018) Phytostabilization potential of ornamental plants grown in soil contaminated with cadmium. Int. J. Phytorem.,20, 311-320.

10 Hrynkiewicz, K., Złoch, M., Kowalkowski, T., Baum, C., Buszewski, B. (2018). Efficiency of microbially assisted phytoremediation of heavy-metal contaminated soils. Environ Rev.,26(2), 316-332.

11 Lam, E. J., Gálvez, M. A., Cánovas, M., Montofré, I. L., Keith, B. F. (2018). Assessment of the adaptive capacity of plant species in copper mine tailings in arid and semiarid environments. J. Soils Sediments. 18, 2203-2216.

12 Frizzo, T. C.E., Porto, M. L. (2004). Zoneamento da vegetação e sua relação com a ocorrência de estruturas mineralizadas na mina Volta Grande,Lavras do Sul, RS, Brazil. Iheringia Sér Bot. PA.,59(1), 5-12.

13 Boechat, L. C., Pistóia, V. C., Gianelo, C., Camargo, F. A. O. (2016). Accumulation and translocation of heavy metal by spontaneous plants growing on multi-metal-contaminated site in the Southeast of Rio Grande do Sul state, Brazil. Environ. Sci. Pollut. Res.,23(3), 2371-80.

14 Afonso, T. F., Demarco, C. F., Pieniz, S., Quadro, M. S., Camargo, F. A. O, Andreazza, R. (2020). Bioprospection of indigenous flora grown in copper mining tailing area for phytoremediation of metals. J. Environ. Manage.,256, 109953.

15 Barroso GM. 1991. Systematics of angiosperms in Brazil. Viçosa (BR): Imprensa Universitária.

16 Amaral, A. S., Mossi, A. J., Radünz, L. L., Treichel, H., Teixeira, A. J., Lerin, L. A., Argenta, G. A. (2010). Crop of Baccharis trimera in nutrient solution with different concentrations of nitrogen, phosphorus and potassium. Perspectiva Erechim,34,25-34.

17 Barroso, G. M. (1976). Compositae - subtribo Baccharidinae hoffmann, study of species occurring in Brazil Rodriguesia, 40, 3-273.

18 Piantino, C. R. (2008). Extraction of phenolic compounds from alecrim-docampo (Baccharisdracunculifolia) using supercritical carbon dioxide [dissertation]. Campinas (BR): Food Engineering Program, UNICAMP.

19 Fagundes, M., Fernandes, G. W. (2011). Insect herbivores associated with Baccharis dracunculifolia (asteraceae): responses of gall-forming and freefeeding insect herbivores to latitudinal variation. Rev. Biol. Trop.,59(3), 114.PMID: 22017142.

20 Sforcin, J. M., et al. (2012). Baccharis dracunculifolia: one of the main plant sources of Brazilian propolis.São Paulo (BR):UNESP.

21 Safford, H. D. (2001). Brazilian Páramos. III. Patterns and rates of postfire regeneration in the campos de altitude. Biotropica. 33(2), 282-302. 
22 Negreiros, D., Esteves, D., Fernandes, G. W., Berbara, R. L. L., Oki, Y., Vichiato, M., Chalub, C. (2014). Growth-survival tradeoff in the widespread tropical shrub Baccharis dracunculifolia (asteraceae) in response-to a nutrient gradient. Trop. Ecol.,55, 167-176. ISSN: 0564-3295.

23 CONAMA, MMA. (2008). The basic parameters of the succession stages of the altitude fields associated with mixed tropical forest, dense tropical forest and semi-deciduous and deciduous seasonal forests in the Atlantic Forest biome. Brasília (BR):CONAMA, MMA.

24 Silva, R. M. G., Oliveira, V. M., Valadares, F., Mecina, G. F., Silva, L. P. (2012). Genotoxic activity and toxicity of Baccharis trimera Less. regarding the bioaccumulation of heavy metals. J. Med. Plants Res., 6(26), 4321- 4327.

25 IBGE. 2012. Manual Técnico de Vegetação Brasileira. Rio de Janeiro (BR): IBGE.

26 Brasil. (2006). National water resources plan. Vol. 4, National programs and targets; Brasília (BR): MMA.

27 EMBRAPA. (2013). Brazilian soil classification system. Brasília (BR): EMBRAPA.

28 Teixeira, G., Gonzalez, A. P., Gonzalez, M. A., Licht, O. A. B. (1978).Contribution to the study of disseminated cuprifferous mineralizations in the Minas do Camaquã district. In: Brazilian Congress of Geology., 4,1644-1654.

29 Hunter, A. H. (1975). Laboratory Analysis of Vegetal Tissues Samples. North Carolina University, Raleigh.

30 Tedesco, M. J., Gianello, C., Bissani, C. A., Bohnen, H., Volkweiss, S. J. (1995). Analysis of soil, plants and other materials. Porto Alegre (BR): UFRGS, Soil Department.

31 Landon, J. R. (1991). Booker Tropical Soil Manual. Longman Scientific and Technical, NY, USA.

32 USEPA. (1998). Method 3050B acid digestion of sediments, sludges, and soils. United States Environmental Protection Agency.https://www.epa.gov/sites/production/files/2015-06/documents/epa3050b.pdf. [accessed 2020 Dec 20].

33 Rezvani, M., Zaefarian, F. (2011). Bioaccumulation and translocation factors of cadmium and lead in Aeluropus littoralis. Aust. J. Agric. Eng.,2(4), 114.

34 Jamil, S., Abhilash, P. C., Singh, N., Sharma, P. N. (2009). Jatropha curcas: a potential crop for phytoremediation of coal fly ash. J. Hazard. Mater., 172, 269275.

35 Kamari, A., Yusoff, S. N. M., Putra, W. P., Hashim, N., Mohamed, A., Phillip, E. (2014). Metal uptake in water spinach grow on contaminated soil amended with chicken manure and coconut tree sawdust. Environ. Eng. Manag. J.,13(9), 2219-2228.

36 Mertens, J., Luyssaert, S., Verheyen, K. (2005). Use and abuse of trace metal concentrations in plant tissue for biomonitoring and phytoextraction. Environ. Pollut., 138(1), 1-4.

37 García, G., Faz, Á., Cunna, M., (2004). Performance of Piptatherum miliaceum (Smilo grass) in edaphic $\mathrm{Pb}$ and $\mathrm{Zn}$ phytoremediation over a short growth period Int. Biodeterior. Biodegrad.,54, 245-250.

38 Santos, R. F., Lima, L., Altivo, F. S., Lalla, J. G., Ming, L. C. (2011). Phytomass production, content, and productivity of essential oil of Baccharis dracunculifolia DC. as affected by organic compound. Rev. Bras. Plant. Med.,13, 574-581. 
39 Kanawate, E. N., Carvalho, R. I. N. (2008). Evaluation of productive process stages and botany identification of Baccharis and Maytenus species collected in metropolitan region of Curitiba. Rev. Acad. Cienc. Agrár. Ambient.,6(4), 73-81.

40 Boldt, P. E. (1989). Baccharis (asteraceae): a review of its taxonomy, phytochemistry, ecology, economic status, natural enemies and the potential for its biological control in the United States. TX. Agric Exp Station., 1674, 32.

41 Espírito-Santo, M. M., Fernandes, G. W. (1998). Abundance of Neopelma baccharidis (homoptera: psyllidae) galls on the dioecious shrub Baccharis dracunculifolia (asteraceae). Environ. Entomol.,27(4), 870-876.

42 Budel, J. M., Duarte, M. R. (2009). Comparative morphoanatomical analysis of two species of carqueja: Baccharis microcephala DC. e B. trimera (Less.) DC., asteraceae. Braz. J. Pharm. Sci.,45(1), 75-85.

43 Gomes, V., Fernandes, G. W. (2002). Germination of Baccharis dracunculifolia DC. (asteraceae) achene. Acta. Bot. Bras., 16(4), 421-427.

44 Palácio, C. P. A. M., Biasi, L. A., Nakashima, T., Serrat, B. M. (2007). Biomass and essential oil yield of carqueja (Baccharis trimera (Less) DC.) under different nitrogen source and levels. Rev. Bras. Plant Med. Botucatu., 9(3), 58-63.

45 Neto, R. M. R., Gama, J. R. V. (2003). Above-ground biomass of herbaceous and shrub species with medicinal potential in a secondary vegetation. Cienc. Florestal., 13, 19-24.

46 Gilberti, L. H. (2012). The potential of Baccharis dracunculifolia DC (asteraceae) for the phytoremediation of arsenic contaminated áreas [dissertation].Belo Horizonte (BR): Institute of Biological Sciences, UFMG.

47 Gilberti, L., Menezes, A., Rodrigues, A. C., Fernades, G. W., Berbara, R. L. L., Marota, H. B. (2014). Effects of arsenic on the growth, uptake and distribution of nutrients in the tropical species Baccharis dracunculifolia DC (asteraceae). Eur. J. Toxicol. Sci.,2014, 1-27.ISSN: 2052-5230.

48 Porto, M. L. (1989). Copper tolerance in ecotypes of Schinus lentiscifolius March (anacardiaceae) in mining regions of Rio Grande do Sul. Acta Bot. Bras.,3(2), 23-31.

49 Melo-Júnior, J. C. F., Amorim, M. W., Severino, A. L., Oliveira, T. M. N., Barros, V. G. (2015). Diversity and community structure of vegetation in natural regeneration in an area of dump off. Acta Biol. Catarinense. 2, 32-47.

50 Prasad, M. N. V. (2015). Geobotany-biogeochemical prospecting. The Paleobotanist.,64(2015), 113-116.

51 Wei, S. H., Zhou, Q. X., Wang, X. (2005). Identification of weed plants excluding the absorption of heavy metals. Environ. Int.,31(6), 829-834.

52 Estrada, B. M., Calderón, J., Sánchez, E. M., Zavala, J. S. R. (2013). Accumulation of arsenic, lead, copper, and zinc, and synthesis of phytochelatins by indigenous plants of a mining impacted area. Environ. Sci. Pollut. Res. Int.,20(6), 3946-55.

53 Menares, F., Carrasco, M. A., González, B., Fuentes, I., Casanova, M. (2017). Phytostabilization ability of Baccharis linearis and its relation to properties of a tailings-derived technosol. Water Air Soil Pollut.,2017, 228-182.

54 Cai, Y., Ma, L. Q. (2003). Metal tolerance, accumulation, and detoxification in plants with emphasis on arsenic in terrestrial plants. In: Cai $\mathrm{Y}$, Braids $\mathrm{O}$,editors. Biogeochemistry of environmentally important trace elements.: London (UK): University Press. p. 95-114.

55 Haque, N., Peralta-Videa, J. R., Jones, G. L., Gill, T. E., Gardea-Torresdey, J. L. (2008). Screening the phytoremediation potential of desert broom (Baccharis 
sarothroides gray) growing on mine tailings in Arizona, USA. Environ. Pollut., 153, 362-368.

56 Reeves, R. D., Baker, A. J. M. (2000). Metal accumulating plants. In: Raskin I, Ensley BD, editors. Phytoremediation of toxic metals: using plants to clean up the environment. New York (USA): John Wiley and Sons Inc. p. 193-229.

57 Shen, Z., Wang, Y., Chen, Y., Zhang, Z. (2017). Transfer of heavy metals from the polluted rhizosphere soil to celosia argentea L. in copper mine tailings. Hortic. Environ. Biotechnol.,58, 93-100.

58 Zhao, F. J., Hamon, R. E., Lombi, E., McLaughlin, M. J., McGrath, S. P. (2002). Characteristics of cadmium uptake in two contrasting ecotypes of the hyperaccumulator thlaspi caerulescens. J. Exp. Bot.,53(368), 535-543.

59 Kabata-Pendias, A. (2010). Trace elements in soils and plants. Boca Raton (FL): CRC Press.

60 Karrfalt, R. P., Olson, D. F. (2008). Baccharis L. In: Bonner FT, Karfalt $\mathrm{RP}$,editors. The woody plant seed manual. USDA/Forest Service, Starkville. p. 291-294.

61 Santos, R., Citadini-Zanette, V., Leal-Filho, L., Hennies, W. T. (2008). Spontaneous vegetation on overburden piles in the coal basin of Santa Catarina, Brazil. Restor. Ecol., 16(3), 444-452.

62 Barbosa, K. C., Pizo, M. A. (2006). Seed rain and seed limitation in a planted gallery forest in Brazil. Restor. Ecol., 14, 504-515.

63 Silva, P. S. C., Francisconi, L. S., Gonçalves, R. D. M. R. (2016). Evaluation of major and trace elements in medicinal plants. J. Braz. Chem. Soc.,27(12), 2273-2289.

64 León-Romero, M. A., Soto-Ríos, P. S., Nomura, M., Nishimura, O. (2018). Effect of steel slag to improve soil quality of tsunami-impacted land while reducing the risk of heavy metal bioaccumulation. Water Air Soil Pollut.,229, 12.

65 Andreazza, R., Bortolon, L., Pieniz, S., Bento, F. M., Camargo, F. A. O. (2015). Evaluation of two brazilian indigenous plants for phytostabilization and phytoremediation of copper-contaminated soils. Braz. J. Biol. 75,868-877.

66 FEPAM. (2014). Portaria no 5, dispõe sobre o estabelecimento de valores de referência de qualidade (VRQ) dos solos para 09 (nove) elementos químicos naturalmente presentes nas diferentes províncias geomorfológicas/geológicas do Estado do Rio Grande do Su). Porto Alegre (BR):FEPAM.

67 CONAMA. (2013). Resolution $\mathrm{n} \div 460$, provides criteria and values guiding soil quality as to the presence of chemical substances. Brasília (BR):CONAMA.

68 EMBRAPA. (2010). Soil fertility and management concepts suitable for climatic regions. Campinas (BR):EMBRAPA.

69 SBCS-NRS. (2016). Manual de adubação e calagem RS e SC., Porto Alegre (BR): Comissão de Química e Fertilidade do Solo - RS/SC. 
621 Table 1Chemical-physical characteristics of copper mining tailings.

\begin{tabular}{llll}
\hline \multicolumn{2}{l}{ Tailigns Texture } & Value in Tailings & Ref. Value \\
\hline Clay & $\%$ & 13.0 & $41.0-60.0 \mathrm{e}^{*}$ \\
$\mathrm{pH}$ & $1: 1$ & 6.2 & $6.0-6.5 \mathrm{~d}$ \\
$\mathrm{OM}$ & $\%$ & 0.5 & - \\
$\mathrm{CEC}$ & $\mathrm{cmol}_{\mathrm{c}} \mathrm{dm}^{3}$ & 6.7 & $>15.0 \mathrm{e}$ \\
$\mathrm{Na}$ & $(\mathrm{mg} / \mathrm{kg})$ & 9.3 & $5000.0 \mathrm{~d}$ \\
$\mathrm{P}$ & $(\mathrm{mg} / \mathrm{kg})$ & 77.0 & $800.0 \mathrm{~d}$ \\
$\mathrm{~S}$ & $(\mathrm{mg} / \mathrm{kg})$ & 1.2 & $700.0 \mathrm{~d}$ \\
$\mathrm{Mn}$ & $(\mathrm{mg} / \mathrm{kg})$ & 11.0 & $418.0 \mathrm{c}$ \\
$\mathrm{Cu}$ & $(\mathrm{mg} / \mathrm{kg})$ & 259.7 & $7.0-11.0 \mathrm{a}$ \\
$\mathrm{Zn}$ & $(\mathrm{mg} / \mathrm{kg})$ & 0.9 & $19.0-20.0 \mathrm{a}$ \\
$\mathrm{Cd}$ & $(\mathrm{mg} / \mathrm{kg})$ & $<0.2$ & $0.3-0.4 \mathrm{a}$ \\
$\mathrm{Cr}$ & $(\mathrm{mg} / \mathrm{kg})$ & 15.3 & $16.0-21.0 \mathrm{a}$ \\
$\mathrm{Ni}$ & $(\mathrm{mg} / \mathrm{kg})$ & 9.0 & $4.0-7.0 \mathrm{a}$ \\
$\mathrm{Pb}$ & $(\mathrm{mg} / \mathrm{kg})$ & $<2.0$ & $13.0-16.0 \mathrm{a}$ \\
$\mathrm{Ba}$ & $(\mathrm{mg} / \mathrm{kg})$ & 0.3 & $\leq 150 \mathrm{~b}$ \\
$\mathrm{Mo}$ & $(\mathrm{mg} / \mathrm{kg})$ & 3.3 & $\leq 30 \mathrm{~b}$ \\
\hline
\end{tabular}


Table 2Phytoremediation indexes by B. dracunculifolia and B. trimera.

\begin{tabular}{|c|c|c|c|c|c|}
\hline \multirow[b]{2}{*}{ Metals } & \multicolumn{5}{|c|}{ B.dracunculifolia } \\
\hline & TF & BCF & $\begin{array}{c}\text { MER } \\
----\% \text { \%--- }\end{array}$ & \multicolumn{2}{|c|}{ number of plants } \\
\hline $\mathrm{Cu}$ & $0.41 a^{*}$ & $0.77 b$ & $0.40 c$ & $8,586 b$ & $1,308 b$ \\
\hline $\mathrm{Zn}$ & $1.12 \mathrm{a}$ & $24.01 b$ & $21.78 c$ & $35,635 b$ & $10,666 b$ \\
\hline $\mathrm{Fe}$ & $1.03 a$ & $n d^{* *}$ & nd & $405 b$ & $116 b$ \\
\hline $\mathrm{Cd}$ & $1.09 a$ & $1.14 b$ & $0.29 c$ & $21,754,045 a$ & $2,290,952 a$ \\
\hline $\mathrm{Cr}$ & $1.08 \mathrm{a}$ & $2.20 b$ & $1.07 c$ & $35,820 b$ & $7,512 b$ \\
\hline $\mathrm{Ni}$ & $0.92 a$ & $1.60 b$ & $0.75 c$ & $87,946 b$ & $18,119 b$ \\
\hline $\mathrm{Pb}$ & $1.12 \mathrm{a}$ & $2.18 b$ & $1.31 c$ & $139,871 b$ & $47,308 b$ \\
\hline $\mathrm{Al}$ & $0.81 a$ & nd & nd & $806 b$ & $162 b$ \\
\hline Co & $0.45 a$ & nd & nd & $6,999,739 b$ & $578,942 b$ \\
\hline $\mathrm{Ba}$ & $0.78 a$ & $603.16 a$ & $245.27 b$ & $6,349 b$ & $1,564 b$ \\
\hline \multirow[t]{2}{*}{$\mathrm{V}$} & $0.86 a$ & nd & nd & $426,894 b$ & $111,162 b$ \\
\hline & \multicolumn{5}{|c|}{ B. trimera } \\
\hline Metals & $\overline{\mathrm{TF}}$ & $\mathrm{BCF}$ & $\begin{array}{l}\text { MER } \\
----\%---- \\
\end{array}$ & \multicolumn{2}{|c|}{ number of plants } \\
\hline $\mathrm{Cu}$ & $0.23 a$ & $1.83 \mathrm{~b}$ & $1.86 \mathrm{c}$ & $3,349 b$ & $376 b$ \\
\hline $\mathrm{Zn}$ & $0.75 a$ & $17.39 b$ & $20.97 b$ & $24,085 b$ & $6,126 b$ \\
\hline $\mathrm{Fe}$ & $0.36 a$ & nd & nd & $315 b$ & $26 b$ \\
\hline $\mathrm{Cd}$ & $0.23 a$ & $0.99 b$ & $0.86 c$ & $6,089,032 a b$ & $672,261 b$ \\
\hline $\mathrm{Cr}$ & $0.91 a$ & $0.89 b$ & $1.27 c$ & $23,484 b$ & $6,735 b$ \\
\hline $\mathrm{Ni}$ & $0.85 a$ & $0.67 b$ & $0.93 c$ & $56,821 b$ & $15,817 b$ \\
\hline $\mathrm{Pb}$ & $1.11 \mathrm{a}$ & $1.83 b$ & $2.79 c$ & $68,902 b$ & $21 ., 46 b$ \\
\hline $\mathrm{Al}$ & $0.39 a$ & nd & nd & $463 b$ & $39 b$ \\
\hline Co & $0.24 a$ & nd & nd & $929,026 b$ & $103,338 b$ \\
\hline $\mathrm{Ba}$ & $0.98 a$ & 278.00ab & $380.16 a$ & $3,907 b$ & $1,051 b$ \\
\hline V & $0.38 a$ & nd & nd & $214,260 b$ & $20,843 b$ \\
\hline
\end{tabular}

663 TF: translocation factor; BCF: bioconcentration factor; MER: metal extraction ratio, PENs:plant effective number of the shoots; PENt: total plant. *Values are means and, means followed by the same letter within a column are not significantly different at the $95 \%$ confidence level (Tukey's test). ${ }^{*}$ nd means not determined. 

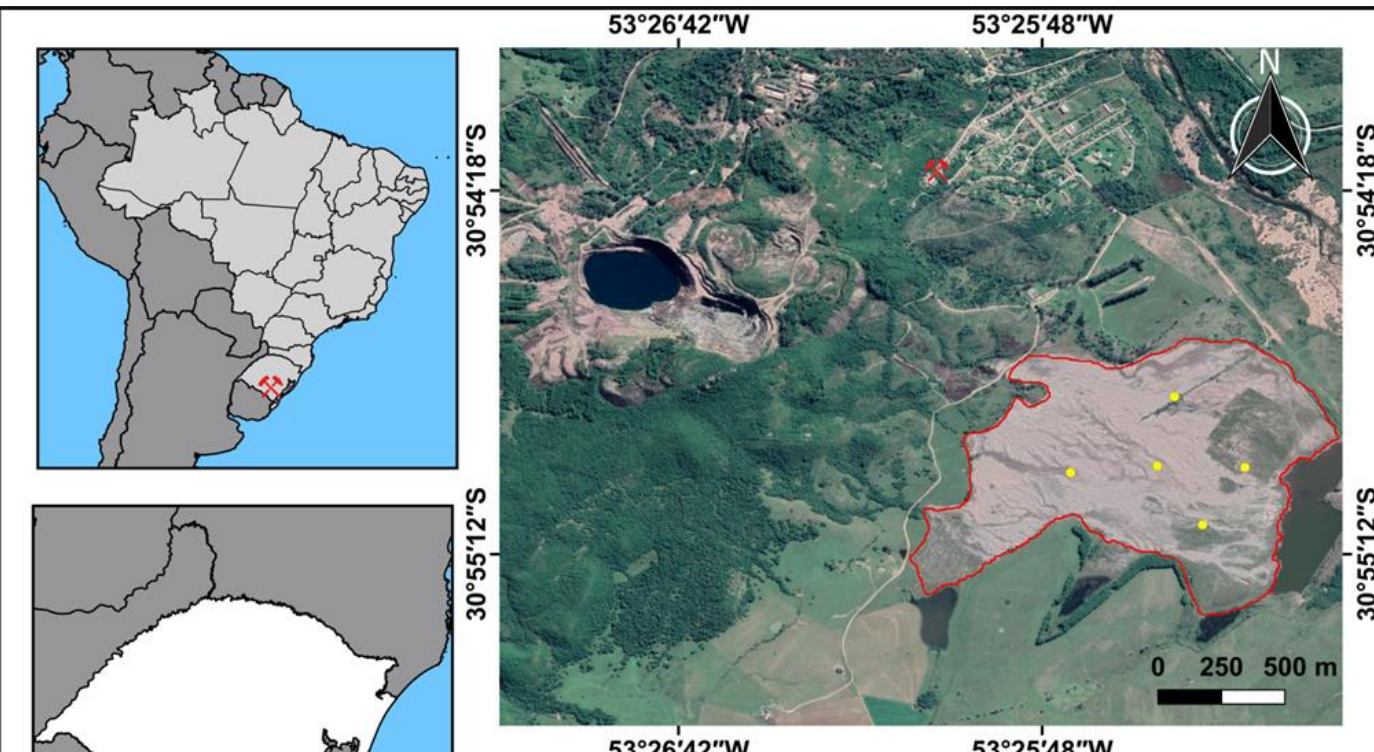

$53^{\circ} 26^{\prime} 42^{\prime \prime} \mathrm{W}$

CRS_DATUM_SIRGAS 2000 (EPSG:4674)

Minas do Camaquã-Caçapava do Sul

Sampling tailing area

Rio Grande do Sul

$\square$ Brazil

$\square$ South America

Fig 1 Location map of the copper mining tailings area, Minas do Camaquã, Southern Brazil. 

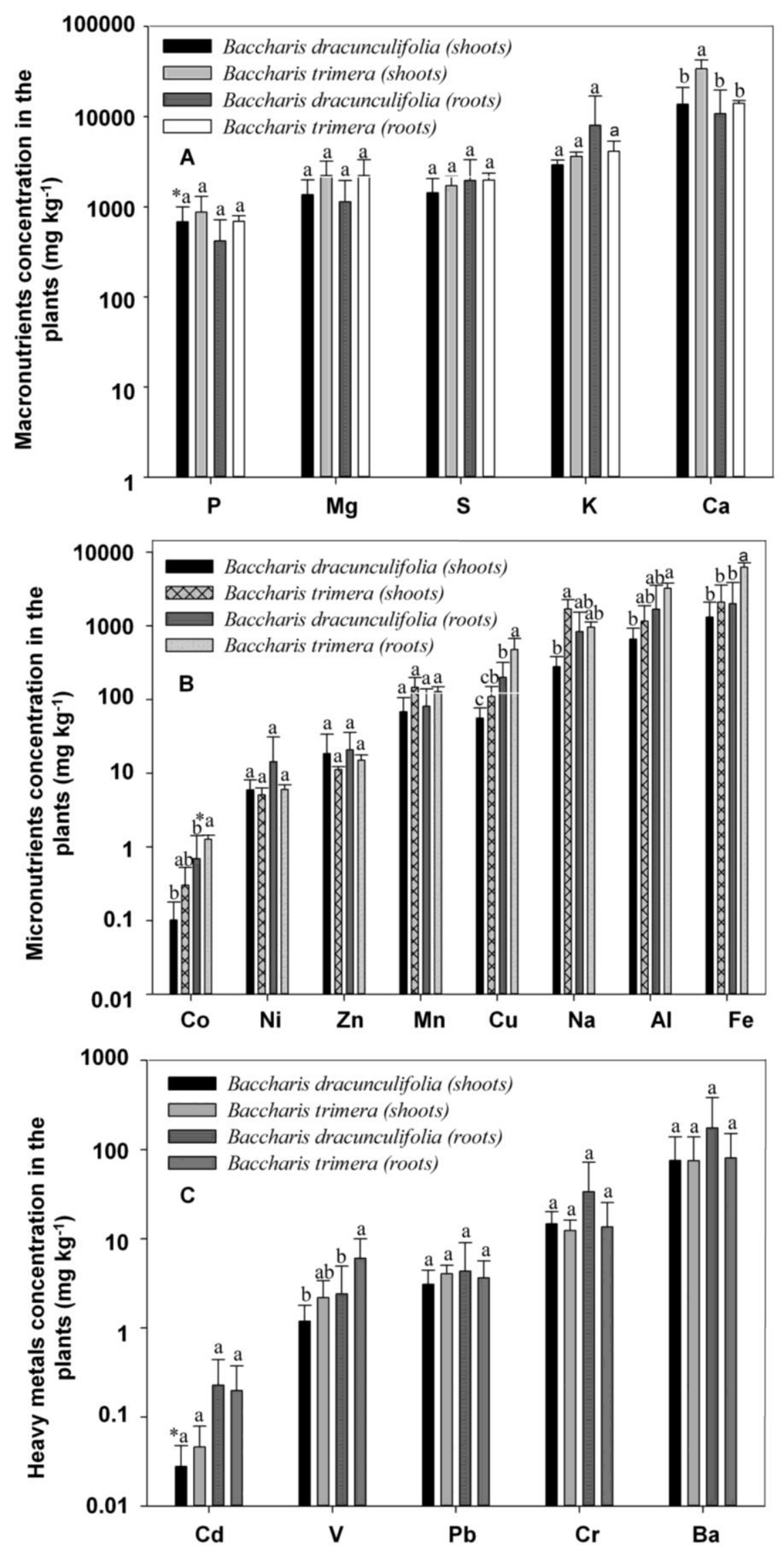

Fig 2Macronutrients (a), micronutrients (b) and heavy metals (c) concentration in dry biomass of $B$. dracunculifolia and $B$. trimera. *Means followed by the same letter within a column are not significantly different at the $95 \%$ confidence level (Tukey's test). 


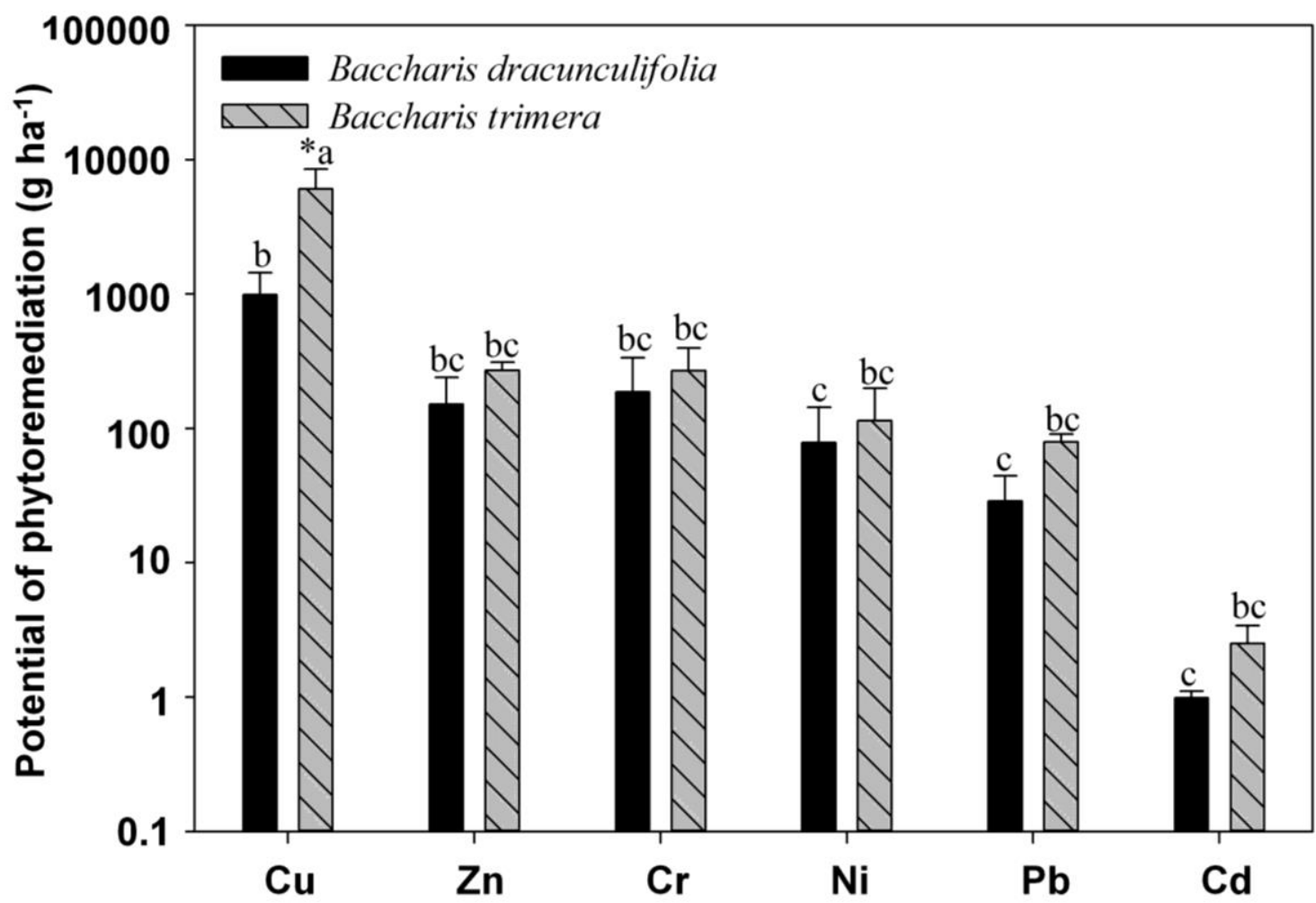

Fig3Potential of phytoremediation of $B$. dracunculifolia and B. trimera. Error bars are calculations of standard error. *Means followed by the same letter within a column are not significantly different at the 95\% confidence level (Tukey's test). 


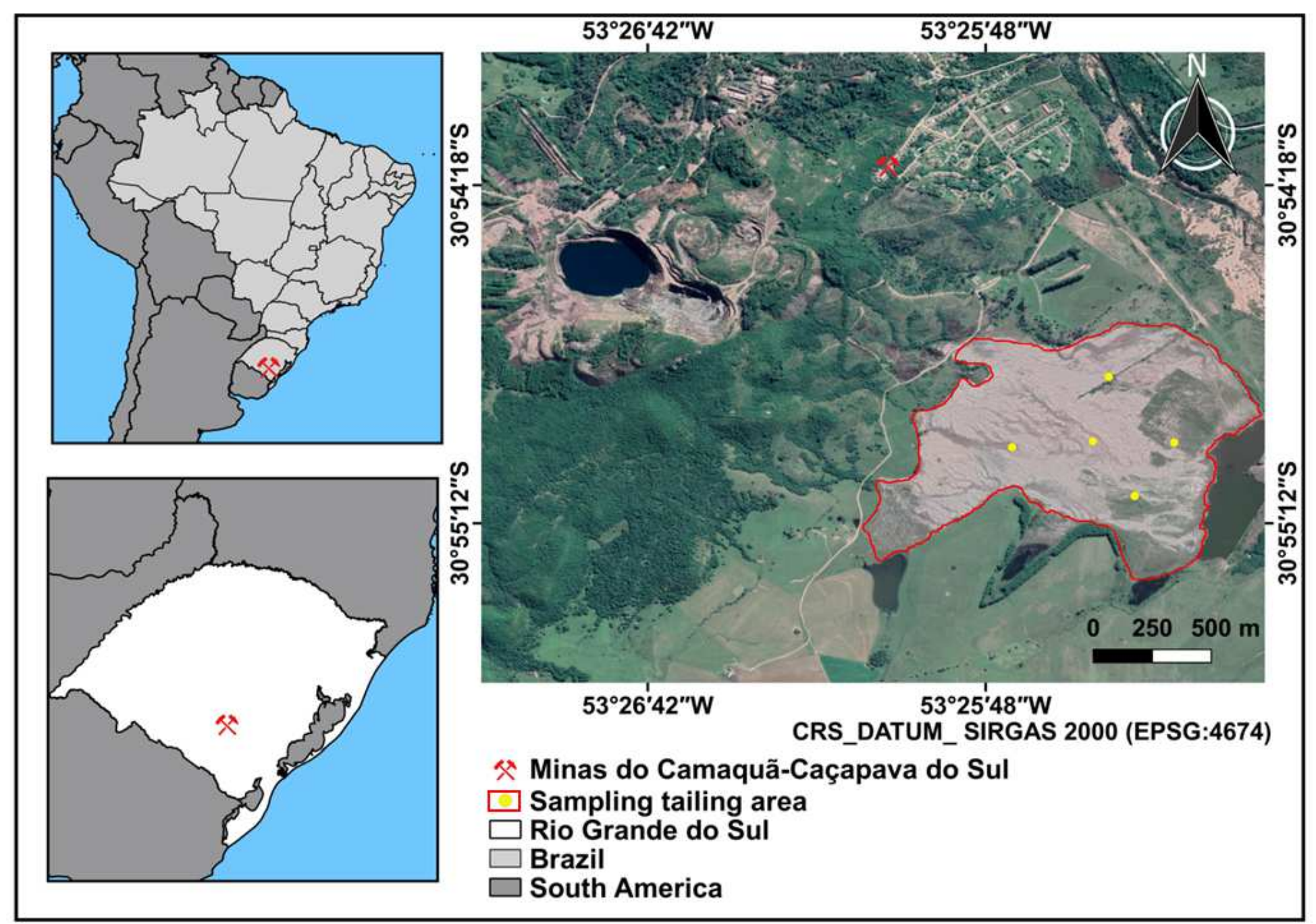

Figure 1

Location map of the copper mining tailings area, Minas do Camaquã, Southern Brazil. Note: The designations employed and the presentation of the material on this map do not imply the expression of any opinion whatsoever on the part of Research Square concerning the legal status of any country, territory, city or area or of its authorities, or concerning the delimitation of its frontiers or boundaries. This map has been provided by the authors. 

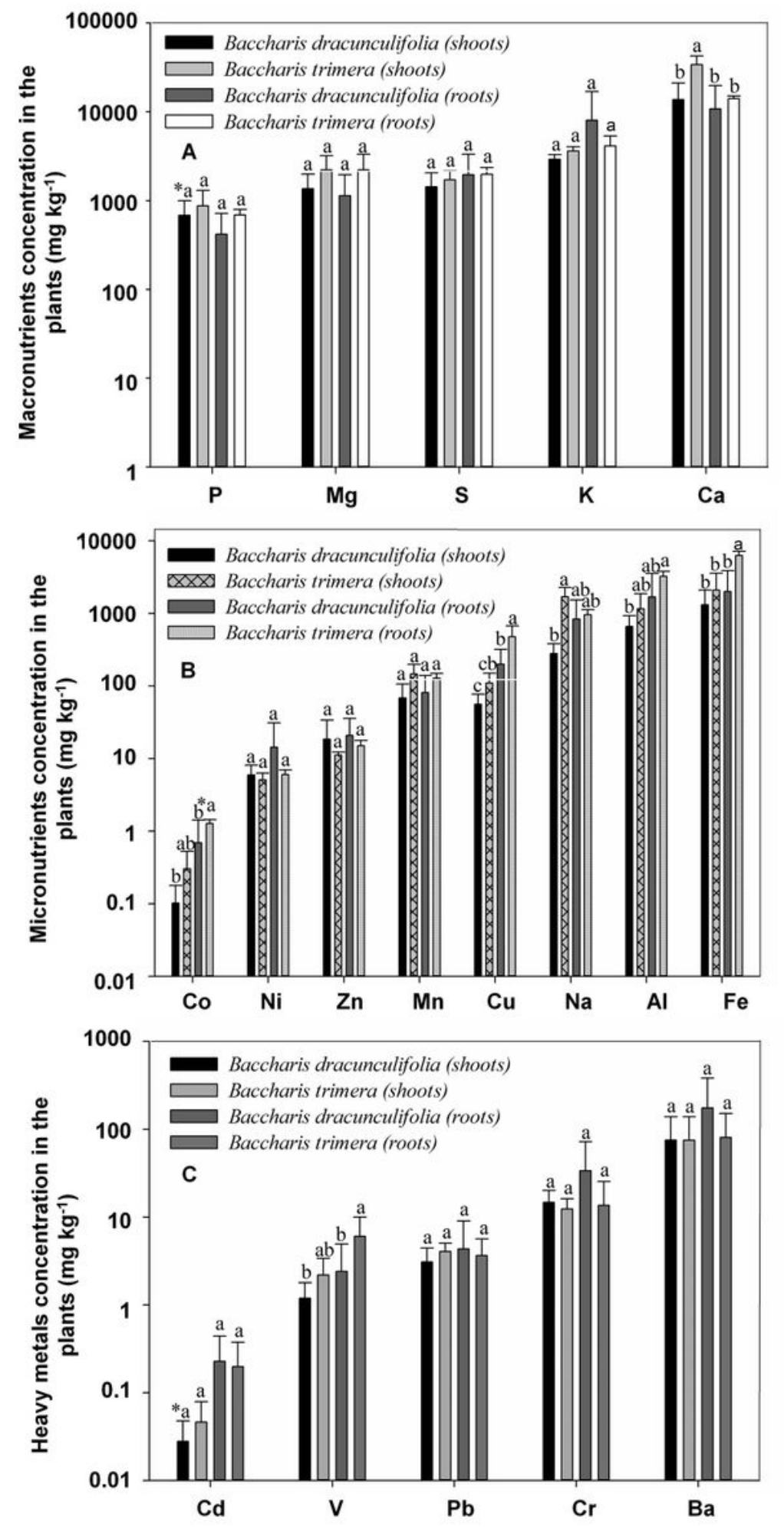

Figure 2

Macronutrients (a), micronutrients (b) and heavy metals (c) concentration in dry biomass of B. dracunculifolia and B. trimera. *Means followed by the same letter within a column are not significantly different at the $95 \%$ confidence level (Tukey's test). 


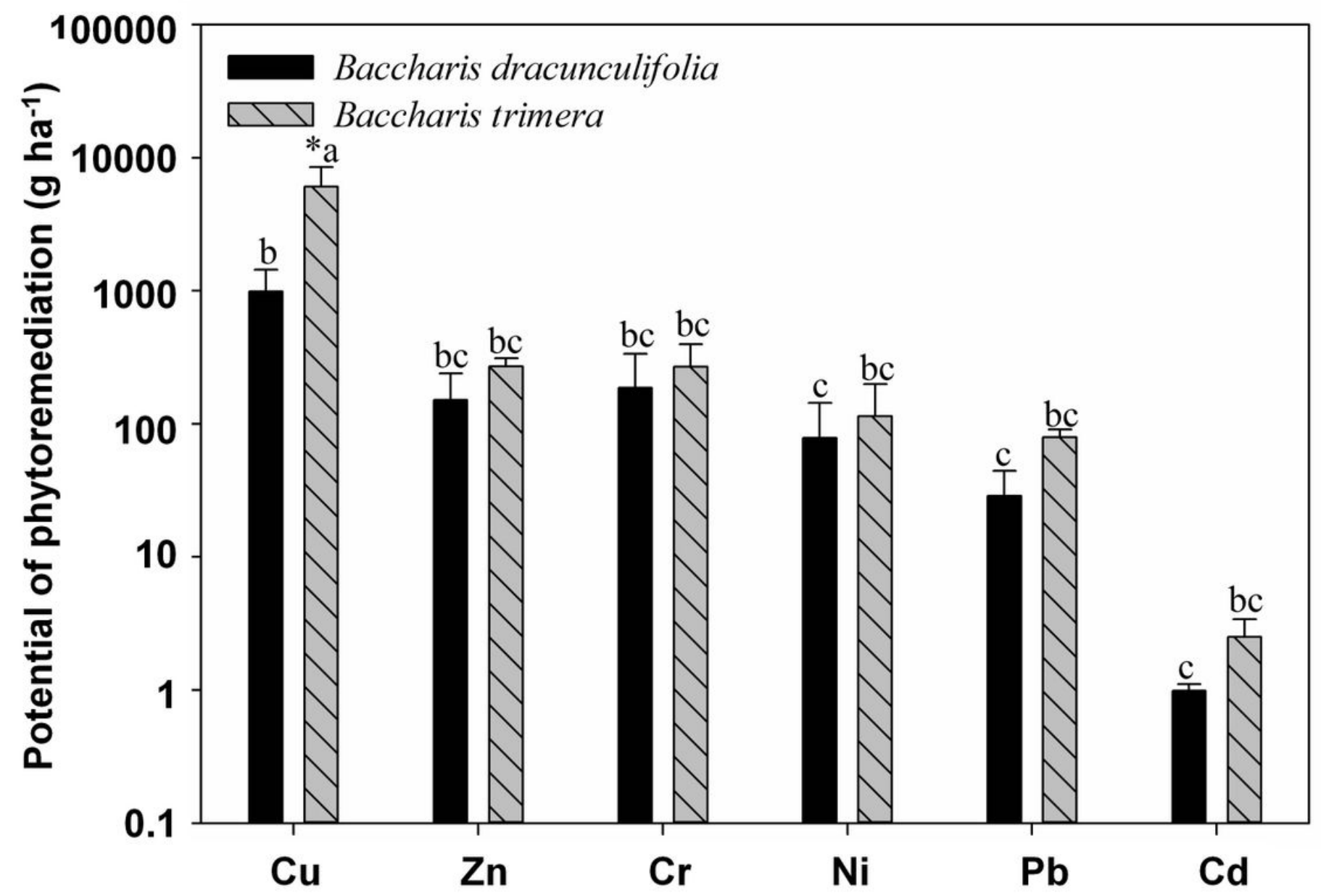

Figure 3

Potential of phytoremediation of B. dracunculifolia and B. trimera. Error bars are calculations of standard error. *Means followed by the same letter within a column are not significantly different at the $95 \%$ confidence level (Tukey's test). 